\title{
EFFECT OF FOLIAR NUTRITION ON GROWTH, GREEN AND FODDER YIELD OF SWEET CORN \\ Al-Betar, A. ${ }^{1}$ and M. Abdou ${ }^{2}$ \\ ${ }^{1}$ Al-Quds Open University. \\ ${ }^{2}$ Fac. of Agric, Suez Canal University, Egypt.
}

\begin{abstract}
Two field experiments were performed at the Jenaan Farm, El-Oweinat East, New Valley Governorate, during the two summer seasons of 2008 and 2009. The main objectives of this study were to determine the effect of three chemical substances (Di-ammonium phosphate, Di-potassium phosphate and Borax ) as a sources of NPK and B nutrients on growth and yield of sweet corn variety Songer. The experiments were laid out in a randomized complete block design with three replicates, under sprinkler irrigation system. The obvious result of this investigation can be summarized as follows:

1- Spraying with Di-ammonium phosphate (as a source of $N$ and $P$ ) favorably influenced the growth parameters, yield attributes and green cob and fodder yields of sweet corn as compared with other treatments.

2- Application of $\mathrm{Di}$-ammonium phosphate at the rate of $7.5 \%$ concentration at 20 and 40 days after sowing significantly increased growth parameters with thicker cobs and corns, and increased the individual cob weight, which in turn increased the green cob yield of sweet corn. Generally, increasing in growth parameters resulted in increasing green fodder yield.

3- Application of NPK and B with different concentrations (0.25 and $0.50 \%)$ failed to influence the growth and yield of sweet corn.
\end{abstract}

Keywords: Sweet corn, foliar nutrition, cob yield, nitrogen, phosphorus, potassium, boron.

\section{INTRODUCTION}

Throughout the world, especially in Europe there is a great demand for fresh and good quality vegetables. Sweet corn is one such newly evolved vegetable; it is the de-husked corn cob harvested within 2-4 days of silk emergence. The importance and use of this corn product is little known to the Egyptian farmers in spite of the fact that it fetches very lucrative prices in the local and international markets.

The growth of any plant is determined mainly in terms of its plant height, photosynthetic attributes and accumulation of photosynthesis in terms of a dry matter and its contents. These growth parameters are affected by the nutrition given to the plant.

Foliar application of nitrogen $(\mathrm{N})$, phosphorus $(\mathrm{P})$ and potassium $(\mathrm{K})$ maintains leaf nutrition in photosynthesis, enhances $\mathrm{N}, \mathrm{P}$ and $\mathrm{K}$ content, carbon $(C)$ balance and self-destructive mechanisms that have resulted in higher yields in crop plants (Boote et al., 1978). Increasing the yield due to foliar nutrition in different crops has been well documented previously (Singh et al., 1999 and Ali and Mishra, 2001). 
Phosphorus is one of the indispensable elements to plants and application of $P$ fertilizers can promote root growth, enhance utilization of soil nutrients and water that taken up by plant roots and finally increase crop yield and improve yield quality (Geo et al., 1989 and Li et al., 1995). Absorption and reduction of nitrate is an energy-consuming process, and the energy is supplied by adenosine tri-phosphate (ATP) that contains $P$ consequently the metabolism of nitrate is related to $P$ supply (Wang and $\mathrm{Li}, 1996$ ). Phosphorus nutrient spray as Di-Ammonium phosphate (DAP) at $2 \%$ concentration is commonly recommended for almost all the pulses (Crop production Guide, 1999).

Potassium is the most abundant cation in plant cells. It is known to be involved in osmotic regulation (Rains, 1976), membrane transport (Ball et al., 1987), metabolic process, and the enzymatic reaction (Suelter, 1970 ; Evans and Wildes, 1971 and Bewley et al., 1983). There are more than 50 enzymes that either completely depend on or are stimulated by potassium (Suelter, 1970).

Similarly, Boron plays an important role in synthesis of protein and translocation of sugars ( Sakal et al., 1990) and increases the yield (Sinha et al., 1999). Enhancement of nutrient content of Potassium, Calcium, Magnesium, Copper, Iron, Manganese, and Zinc in plant tissues due to Boron has also been reported (Ohki, 1975).

However, no reports are available on foliar nutrition on sweet corn production. Keeping this in view, field experiments were carried out.

\section{MATERIALS AND METHODS}

Field experiments were carried out in Jenaan Farm, El-Oweinat East, New Valley Governorate, during the two summer seasons of 2008 and 2009, to determine the effect of three chemical substances (as a sources of NPK and $B$ ) with three concentration on growth and yield of sweet corn variety Songer.

The experiments were laid out in randomized complete block design with three replications. The experiment consisted of 10 treatments. The three chemical substances i.e. Di-ammonium phosphate granular fertilizers contains $18 \% \mathrm{~N}$ and $46 \%, \mathrm{P}_{2} \mathrm{O}_{5}$ (DAP), Di- potassium phosphate contains $62 \% \mathrm{~K}_{2} \mathrm{O}$ and about $38 \% \mathrm{P}_{2} \mathrm{O}_{5}$ (DKP) and Borax contains $10 \%$ Boron (B), each with three concentrations as a source of (NPK and B) plus the control . Each chemical substances was prepared by diluting with water and sprayed on 20 days and 40 days from sowing during afternoon hours. The three concentrations i.e. DAP at $0.25 \%(1.5 \mathrm{~kg} / \mathrm{acre}), 0.50 \%(3.0 \mathrm{~kg} / \mathrm{acre})$ and $0.75 \%$ (4.5 kg/acre), DKP at $0.25 \%$ (1.5 kg/acre), 0.50 (3.0 kg/acre) and $0.75 \%$ (4.5 kg/acre) and B at $0.25 \%$ (1.5 kg/acre), $0.50 \%$ (3.0 kg/acre) and $0.75 \%$ (4.5 kg/acre).

Each experimental basic unit included 5 ridges, each of $60 \mathrm{~cm}$ width and $20 \mathrm{~m}$ length, resulted an area of $60 \mathrm{~m}^{2}$ (1/70 fed). The preceding winter crop was Faba Bean. Sweet corn variety Songer with field duration of 90-95 days was used in the trail. 
The experimental site is located in $30^{\circ} 34^{\prime} 08.37^{\prime \prime} \mathrm{N}$ latitude, $32^{\circ} 10^{\prime} 54.80^{\prime \prime} \mathrm{E}$ longitude and at an elevation $277 \mathrm{~m} \mathrm{MSL}$ and has an arid climate with a hot dry air. Meteorological data (Temperature $\mathrm{C}^{\circ}$, relative humidity $\%$, wind velocity $\mathrm{m} / \mathrm{sec}$, total rainfall $\mathrm{mm} / \mathrm{month}$, mean daily evapotranspiration and soil temperature) of El- Oweinat East district during the two seasons were shown in Table 1.

Table 1: Meteorological data of El- Oweinat East district during the two seasons.

\begin{tabular}{|l|c|c|c|c|c|c|c|c|c|c|c|c|}
\hline Meteorological data & Jan. & Feb. & Mar. & Apr. & May & Jun. & Jul. & Aug. & Sep. & Oct. & Nov. & Dec. \\
\hline $\begin{array}{l}\text { Mean Daily Temperature } \\
\text { Co }^{\circ}\end{array}$ & 12 & 13 & 18 & 24 & 29 & 31 & 30 & 30 & 28 & 26 & 18 & 13 \\
\hline Relative Humidity \% & 43 & 34 & 26 & 19 & 15 & 19 & 18 & 20 & 23 & 25 & 37 & 41 \\
\hline Wind Velocity (m/sec) & 5.3 & 5.1 & 5.7 & 6.7 & 6.6 & 6.8 & 6.1 & 6.5 & 8.0 & 6.3 & 6.5 & 5.1 \\
\hline Total rainfall mm/ month & 0.0 & 0.0 & 0.0 & 0.0 & 0.0 & 0.0 & 0.0 & 0.0 & 0.0 & 0.0 & 0.0 & 0.0 \\
\hline $\begin{array}{l}\text { Mean daily evapotrans. } \\
\text { (mm) }\end{array}$ & 7.7 & 8.0 & 10.1 & 11.0 & 18.0 & 18.6 & 17.9 & 19.3 & 10.0 & 10.9 & 7.5 & 7.8 \\
\hline Soil temperature Co & 16 & 17 & 22 & 27 & 32 & 34 & 35 & 35 & 32 & 30 & 21 & 17 \\
\hline
\end{tabular}

Soil samples were taken at random from the experimental field area at the depth of $90 \mathrm{~cm}$ from soil surface before soil preparation to measure the mechanical and chemical soil properties. Results of mechanical and chemical analysis are presented in Table 2.

Table 2: Soil characteristics (90 cm depth), extraction methods and methods used to measure of the experimental field.

\begin{tabular}{|c|c|c|}
\hline Soil characters & alues & Met \\
\hline (ppm) & 47 & niumnitrate,tomicbsorption/l \\
\hline (ppm) & 2 & $1 \mathrm{M}$ ammonium nitrate, Atomic Absorption/ICP 5:25 \\
\hline Manganese (ppm) & 58 & $\begin{array}{llll}1 & \text { M Ammonium Acetate with } 2 \mathrm{~g} / \mathrm{l} \text { quinol, Atomic } \\
\text { Absorption/ICP 2.5:25 }\end{array}$ \\
\hline Boron (ppm) & 1.0 & $\begin{array}{l}\text { Hot Water }\left(80 \mathrm{C}^{0}\right) \text {, solution spectrophotometery after } \\
\text { coplexing with azomethine 10:25 }\end{array}$ \\
\hline m) & 0.2 & 0.05 M EDTA disodium salt, Atomic absorption/ICP 5:25 \\
\hline m & 0.1 & $\begin{array}{l}\text { Ammonium acetate }(24.9 \mathrm{~g} / \mathrm{l}+\text { oxalic acid }(12.6 \mathrm{~g} / \mathrm{l}) \text { Atomic } \\
\text { absorption with nitrous oxide } 1: 5\end{array}$ \\
\hline pm) & & 0.05 M EDTA disodium salt, atomic absorption/ICP 5:25 \\
\hline $\mathbf{Z i}$ & .6 & 0.05 M EDTA disodium salt, atomic absorption/ICP 5:25 \\
\hline Sulph & 44 & $\begin{array}{l}\text { Calcium tetrahydrogen diorthophosphate, solution } \\
\text { spectrophotometry of precipitated barium sulphate } 40: 100\end{array}$ \\
\hline Sodi & 199 & $\begin{array}{l}\text { 1 M Ammonium nitrate, Flame emission spectrometry/ICP } \\
\text { 5:25 }\end{array}$ \\
\hline $\mathbf{C a}$ & c & Concentrated $\mathrm{HCl}$, volume $\mathrm{C}$ \\
\hline & 85 & $\mathrm{H}_{2} \mathrm{SO}_{4} / \mathrm{H}_{3} \mathrm{PC}$ \\
\hline Pho & 8 & $\begin{array}{l}\text { Olsen (Sodium hydrogen carbonate), } \begin{array}{r}\text { solution } \\
\text { spectrophotometry after complexing with ammonium } \\
\text { molybdate 5:100 }\end{array} \\
\end{array}$ \\
\hline Potassium (ppm) & 85 & $\begin{array}{l}\text { 1 M Ammonium nitrate, Flame emission spectrometry/ICP } \\
5: 25\end{array}$ \\
\hline $\mathbf{P H}$ & 8 & Water, pH electrode/meter 10:25 \\
\hline 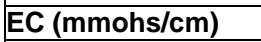 & 1.337 & Water, conductivity of solution $20: 50$ \\
\hline CEC $(\mathbf{m}$ & 2.508 & $\begin{array}{l}\text { Leached with } 1 \mathrm{M} \text { ammonium acetate followed by } 10 \% \\
\text { ion specific electrode for ammonium } 5 \mathrm{~g}: 4 \times 25\end{array}$ \\
\hline
\end{tabular}


The experimental field well prepared and then divided into the experimental units. The base dose of macronutrient fertilizer, nitrogen, phosphorus and potassium were applied in the form of ammonium nitrate (55 $\mathrm{kg} \mathrm{N} / \mathrm{acre}$ ), calcium superphosphate (45 $\left.\mathrm{kg} \mathrm{P}_{2} \mathrm{O}_{5} / \mathrm{acre}\right)$ and potassium sulphate $\left(55 \mathrm{~kg} \mathrm{~K} \mathrm{~K}_{2} \mathrm{O}\right)$. Half of the nitrogen rate and all of potassium and phosphorus were applied at the time of sowing. While, the remaining half of nitrogen was applied 25 days after sowing as top dressing.

Sweet corn grains were hand sown in hills at the rate of 2-3 grains/hill using dry sowing method on one side of the ridge $30 \mathrm{~cm}$ between hills (about 60,000 plant/acre) during $10^{\text {th }}$ June in the first season and $23^{\text {rd }}$ June in the second season. The other agricultural practice was kept the same as normally practiced in sweet corn fields.

De-tasselling was done at the early emergence of tassel from the flag leaf. The cobs were harvested after 2-3 cm length of silk emergence.

ICP Inductively Coupled Plasma Analyzer

For recording various biometric observations on sweet corn, a sample consisting of five plants from each net plot was selected at random and tagged. From the tagged plants, observations on plant height, Leaf Area Index (LAI) and dry Matter Production (DMP) at 55 days and harvest were determined. Plant height was measured from ground level to the tip of flag leaf. The leaves collected from the sample plants were taken to the laboratory and the leaf area was measured by using leaf area meter (LICOR Model 3100). From the leaf area, LAI was calculated:

$$
\text { Leaf area plant }{ }^{-1}
$$

LAI =

\section{Ground area occupied plant}

Dry matter production (DMP) was obtained by drying the plant sample at $70 \mathrm{C}^{\circ}$ until the constant weigh was attained. Days taken to the tassel and cob emergence were noted. The yield parameters, such as the number of cobs per plant, length, width and weight of green cob, length, width and weight of sweet corn, were measured from the sampling plants. Green cob to corn ratio was calculated by dividing the weight of green cobs by the weight of sweet corn. The number of cobs per hectare was obtained by multiplying the number of plants per hectare and the number of cobs per plant. The green cob yield from net plot was harvested on alternate days, weighed and expressed in $\mathrm{kg} \mathrm{ha}^{-1}$.

Statistical analysis of the obtained data was analyzed according to Steel and Torrie (1980), using LSD at 5\% level for comparison between means of the different treatments. Green cob and fodder yields were pooled and analyzed.

\section{RESULTS}

\section{Growth Parameters:}

The data on growth parameters of sweet corn as influenced by foliar nutrition are given in Table 3. Growth parameters such as plant height, LAI and DMP did not vary significantly at 55 days, whereas at harvest, the above 
parameters were significantly influenced by the foliar nutrition during growing season. Application of (DAP) substance containing $\mathrm{N}$ and $\mathrm{P}(0.75 \%)$ promoted all the aforementioned growth parameters significantly. However at lower concentrations of (DAP and MKP) containing N, P and $\mathrm{K}$ at $(0.25$ and $0.50 \%$ ) and also the other nutrients ( $\mathrm{K}$ and $\mathrm{B}$ ) at different concentration failed to influence the growth parameters. Similarly there was no significant variation among the treatments with respect to days to first tasselling and first cob initiation in sweet corn.

Table 3: Influence of foliar nutrition on growth parameters of sweet corn.

\begin{tabular}{|l|c|c|c|c|c|}
\hline Treatments & $\begin{array}{c}\text { Plant height } \\
\mathbf{( c m})\end{array}$ & LAl & DMP (kgha $\left.{ }^{-1}\right)$ & $\begin{array}{c}\text { Days to } \\
\text { Tasselling }\end{array}$ & $\begin{array}{c}\text { Days to cob } \\
\text { initiation }\end{array}$ \\
\hline DAP1-0.25\% & 179.5 & 3.11 & 8153 & 52.6 & 59.6 \\
\hline DAP2-0.50\% & 181.6 & 3.07 & 8275 & 52.3 & 58.0 \\
\hline DAP3-0.75\% & 189.7 & 3.31 & 8910 & 52.0 & 58.0 \\
\hline DKP1-0.25\% & 179.2 & 3.00 & 8336 & 52.0 & 59.6 \\
\hline DKP2-0.50\% & 177.5 & 2.90 & 8114 & 52.0 & 55.0 \\
\hline DKP3-0.75\% & 179.3 & 2.99 & 8100 & 52.6 & 54.6 \\
\hline B1-0.25 & 179.3 & 2.96 & 8314 & 52.0 & 54.6 \\
\hline B2-0.50\% & 175.5 & 2.97 & 8160 & 52.6 & 55.0 \\
\hline B3-0.75\% & 179.9 & 2.93 & 8159 & 52.0 & 54.6 \\
\hline Control & 175.0 & 2.96 & 8179 & 52.6 & 54.3 \\
\hline LSD at. 0.05 & 6.22 & 0.23 & 634 & NS & NS \\
\hline
\end{tabular}

\section{Yield attributes}

Data on the effect of foliar nutrition on the yield attributes of sweet corn are presented in Table 4. During the growing season, the length of cob and corn, and the number of cobs were not influenced by the foliar nutrition. Yield attributes, viz., width of cob and corn, weight of cob and corn, cob-corn ratio, were significantly influenced by foliar nutrition on sweet corn.

Table 4: Effect of foliar nutrients composition and concentration on yield components of sweet corn

\begin{tabular}{|c|c|c|c|c|c|c|c|c|}
\hline Treatments & $\begin{array}{l}\text { No. of } \\
\text { Cobs/ } \\
\text { plant }\end{array}$ & $\begin{array}{c}\text { length of } \\
\text { cob } \\
(\mathrm{cm})\end{array}$ & $\begin{array}{c}\text { Width of } \\
\text { cob } \\
(\mathrm{cm})\end{array}$ & $\begin{array}{c}\text { weight } \\
\text { of cob } \\
\text { (g) }\end{array}$ & $\begin{array}{c}\text { length of } \\
\text { corn } \\
(\mathrm{cm})\end{array}$ & \begin{tabular}{|c|}
$\begin{array}{c}\text { width of } \\
\text { corn } \\
(\mathrm{cm})\end{array}$ \\
\end{tabular} & $\begin{array}{l}\text { weight } \\
\text { of corn } \\
\text { (g) }\end{array}$ & $\begin{array}{l}\text { cob-col } \\
\text { ratio }\end{array}$ \\
\hline DAP1-0.25\% & 2.6 & 21.8 & 3.61 & 46.4 & 10.3 & 1.62 & 10.3 & 4.41 \\
\hline DAP2-0.50\% & 2.4 & 21.6 & 3.64 & 47.0 & 10.4 & 1.64 & 10.4 & 4.50 \\
\hline DAP3-0.75\% & 2.4 & 22.6 & 4.01 & 52.4 & 10.8 & 1.80 & 13.8 & 4.01 \\
\hline DKP1-0.25\% & 2.6 & 21.9 & 3.59 & 45.4 & 10.3 & 1.59 & 10.1 & 4.51 \\
\hline DKP2-0.50\% & 2.4 & 21.3 & 3.57 & 45.9 & 10.4 & 1.59 & 10.3 & 4.47 \\
\hline DKP3-0.75\% & 2.6 & 21.4 & 3.51 & 46.1 & 10.4 & 1.59 & 10.3 & 4.47 \\
\hline B1-0.25\% & 2.4 & 21.7 & 3.58 & 45.3 & 10.4 & 1.63 & 10.2 & 4.41 \\
\hline B2-0.50\% & 2.4 & 21.9 & 3.61 & 45.8 & 10.3 & 1.61 & 10.3 & 4.43 \\
\hline B3-0.75\% & 2.6 & 21.6 & 3.57 & 46.1 & 10.4 & 1.60 & 10.4 & 4.42 \\
\hline Control & 2.6 & 21.3 & 3.56 & 46.0 & 10.3 & 1.59 & 10.4 & 4.41 \\
\hline LSD at 0.05 & NS & NS & 0.28 & 3.8 & NS & 0.13 & 0.81 & 0.37 \\
\hline
\end{tabular}


Foliar application of (DAP) contain $\mathrm{N}$ and $\mathrm{P}(0.75 \%)$ produced thicker cobs and corn, heavier cobs and corn and also reduced the cob-corn ratio as compared to the rest of the sprays. Lower concentration of DAP $(0.25$ and $0.50 \%$ ) and also $\mathrm{K}$ and $\mathrm{B}$, did not have any significant influence on sweet corn yield attributes.

\section{Green cob and green fodder yield}

Data on green cob and green fodder yield of baby corn as influenced by foliar nutrition are given in Table 5 . Green cob and green fodder yields were significantly varied due to foliar application of nutrients. Application of DAP substance contain $\mathrm{N}$ and $\mathrm{P}$ at $0.75 \%$ concentration recorded the highest green cob yield $\left(8910 \mathrm{~kg} \mathrm{ha}^{-1}\right)$ and it was $08.2 \%$ higher over control. Similarly, green fodder yield was also maximum $\left(30.1 \mathrm{t} \mathrm{ha}^{-1}\right)$ with DAP at $0.75 \%$ spray.

Table 5. Influence of foliar nutrients on sweet corn and fodder yields of sweet corn

\begin{tabular}{|lcc|}
\hline & & \\
\hline Treatments & Sweet corn yield $\left(\mathbf{k g ~ a c r e} \mathbf{-}^{-1}\right)$ & Fodder yield $(\mathbf{t}$ acre-1) \\
\hline DAP1-0.25\% & 6459 & 26.1 \\
\hline DAP2-0.50\% & 6549 & 26.5 \\
\hline DAP3-0.75\% & 7039 & 30.1 \\
\hline DKP1-0.25\% & 6406 & 25.7 \\
\hline DKP2-0,50\% & 6433 & 26.1 \\
\hline DKP3-0.75\% & 6513 & 26.1 \\
\hline B1- 0.25\% & 6467 & 26.4 \\
\hline B2- 0.50\% & 6500 & 25.6 \\
\hline B3- 0.75\% & 6532 & 26.0 \\
\hline Control & 6268 & 24.4 \\
\hline LSD at 0.05 & 386.5 & 3.32 \\
\hline
\end{tabular}

However, lower concentrations $(0.25$ and $0.5 \%)$ of $\mathrm{DAP}$, contain $\mathrm{N}, \mathrm{P}$ and also DKP and borax, contain $\mathrm{P}, \mathrm{K}$ and $\mathrm{B}$ with different concentrations failed to influence the green cob and green fodder yields of sweet corn.

\section{DISCUSSION}

The results of the present study revealed that the application of DAP contain $\mathrm{N}$ and $\mathrm{P}$ at $0.75 \%$ concentration significantly increased the growth and yield attributes of green cob and fodder yields of sweet corn. All the growth parameters were influenced by $P$ at $0.75 \%$ concentration. The possible attributed reason for higher growth characters is higher availability of $\mathrm{N}$ and $\mathrm{P}$ to the sweet corn in the $0.75 \%$ DAP applied treatment which might have influenced the growth of sweet corn. Foliar application of $\mathrm{N}$ and $\mathrm{P}$ at two splits (25and 45 days) might have helped in supplementing the nutrient requirement of the crop (Kahn et al., 1993). Thakur et al., (1996) reported that nitrogen and phosphorus enhanced the photosynthetic activity, which led to a better supply of carbohydrates, and ultimately higher dry matter production. 
The yield attributes had a positive relation with $\mathrm{N}$ and $\mathrm{P}(0.75 \%)$ spray. This might be due to the higher photosynthetic attributes such as more retention of green leaves up to harvest (higher leaves area and higher leaves area index to produce more dry matter production which in turn increase the chlorophyll content and higher photosynthetic activity in sweet corn. Both width and weigh of cob and corn were increased. The ratio of cob-corn was reduced due to the $\mathrm{N}$ and $\mathrm{P}$ spray explaining the higher economic part (corn) and reduced sheath in sweet corn. Kalarani and Jayakumar (1998) suggested that $\mathrm{N}$ and $\mathrm{P}$ spray as Di-ammonium phosphate (DAP) enhanced the NRase activity due to the enhancement of $\mathrm{N}$ uptake and photosynthetic activity which resulted in higher chlorophyll ii content, essential for higher enzyme activity. Higher green cob and green fodder yields were obtained with $\mathrm{N}$ and $\mathrm{P}$ at $.075 \%$ foliar nutrition than other nutrients and concentrations.

The possible reason might be the increased growth parameters that enhanced the yield attributes, in turn increasing green cob yield of sweet corn. Higher growth parameters such as plant height, LAI and DMP attributed higher green fodder yield over other treatments. The waste of $N$ and $P$ nutrients like leaching, fixation, volatilization, etc. can be enhanced by foliar application, which has been shown to be effective, economical in some crops (Afridi and Wasiudden, 1979). Increased yield due to nitrogen and phosphorus nutrition was earlier documented (Thakur et al., 1996 ; Kalarani and Jayakumar, 1998 and Thavaprakaash et al., 2006).

The current study suggest that the application of DAP as a source of $\mathrm{N}$ and $\mathrm{P}$ as a compound fertilizer at $0.75 \%$ concentration during (early vegetative stages ( 25 and 45 days from sowing) increases the growth and yield attributes of green cob and green fodder yields of sweet corn. Recommending this practice will improve the net outcome of farmers. A further study is needed on the physiological basis of $\mathrm{Di}$ and/or-ammonium phosphate on enhanced productivity of sweet corn.

\section{REFERENCES}

Afridi, M.M. and Wasiuddin, R.K. (1979). Foliar fertilization of crop plants, A Review In" Recent Researches in Plant Sciences". New Delhi, India: Kalyani Publishers, PP: 390-394.

Ali, M. and Mishra, J. P. (2001). Effect of foliar nutrition of boron and molybdenum on chickpea. Ind. J. pulses 14:41-43. Alvaret- Tinault MC, Leal A, Martinez LR. 1980. Iron- manganese interaction and its relation to boron levels in tomato plants. Plant Soil, 55:377-388.

Ball, M. C. ; Chow, W. C and Anderson J. M. (1987). Salinity induced potassium deficiency causes loss of functional photosystem ii in leaves of the grey mangrove, Avicennia marina, deletion of the atrazinebinding polypeptids. Aus. J. Plant Physiol., 14:351-361. 
Bewley, J. F. ; Larsen, J. D and Pappi J.E.T. (1983). Water stress induces changes in the pattern of protein synthesis in maize seedlings mesocotyls: A comparison with the effect of heat shock. J. Experim. Botany, 34: 1126-1133.

Boote, J. B.; Gallaher, R. N.; Robertson, W. K., and Hammons, L. C.(1978). Effect of foliar fertilization on photosynthesis, leaf nutrition and yield of Soybean. Agron J., 70:786-791.

Crop Production Guide (CPG) (1999). Crop Production Guide. Chennai: Directorate of Agriculture and Coimbatore, TNAU.

Evans, H. J. and Wildes, R.A. (1971). Potassium and its role in enzyme activation. In: $8^{\text {th }}$ Collog Int. Potash Inst. Bern, PP: 1-39.

Geo, Z. M.; Zhang, Y.D.; Shi, D. Y. and Zhang, M. F. (1989). Effect of N, P and $\mathrm{K}$ on accumulation of nitrate and the activity of nitrate reductase and super oxidase in leafy Vegetables. Acta Hort., 16: 293-298.

Jackson, M.L. (1967). Soil Chemical Analysis. New Delhi: Prentice Hall of India Pvt. Ltd.

Kahn, N.A. Samiuilah and Aziz, O. (1993). Response of mustard to seed treatment with pyridoxine and basal and foliar application of nitrogen and phosphorus. J. Plant Nutrition, 16: 1651-1659.

Kalarani, M.K. and Jayakumar, P. (1998). Effect of nutrients and NAA spray on physiological changes in soybean (Glycine max L. Merill). Indian J. Plant Physiol., 3: 226-228.

Li, S. Q.; Li, S.X and Tian, X.N. (1995). Interaction effect of water and fertilizers on wheat yields and fertilizer efficiency. In: Wang, D. S, editor. The principles of relationship between fertilizer and water of dry land farming lands and its regulation technology. Beijing: Chinese Agricultural Science and Technology Press. PP: 246-262.

Ohki, K. (1975). Mn and B effects on micro nutrients and $P$ in cotton. Agronomy J., 67: 204-207.

Piper, C. S. (1966). Soil and Plant Analysis. Bombay: Hans publications.

Rains, D. W. (1976). Mineral Metabolism. In: Bonner J, Verner J.E., editors. Plant Biochemistry. $3^{\text {rd }}$ ed. New York: Academic Press. pp: 561-597.

Sakal, R. ; Sinha, R. B. and Singh, A.P. (1990). Response of Chickpea to boron application in calcareous soils. Int. Chickpea News, 22: 28-29.

Singh, M. ; Kumar, R. ; Tomer, D.P. and Singh, R.C. (1999). Response of chickpea to micronutrients. Haryana J. Agron., 15: 179-182.

Sinha, A.K.; Singh, C. and Jain, B.P. (1999). Effect of micronutrients and growth regulators on yield and quality of Litchi (Litchi chinensis Sonn.). J. Res., 11: 45-48.

Steel, R.G. and Torrie, J.H. (1980). Principle and Procedures of Statistics. $2^{\text {nd }}$ ed. McGraw-Hill book Co., New York.

Suelter, C. H. (1970). Enzymes activity by monovalent cations. Science, 168: 789-795.

Thakur, V.R. ; Giri, D.G. and Deshmukh, J.P. (1996). Influence of different sources and levels of phosphorus on yield and uptake of green gram (Vigna radiate L.). Ann. Plant Physiol, 10: 145-147. 
Thavaprakaash, N. ; Velayudham, K. and Panneerselvam, S. (2006). Foliar nutrition of baby corn (Zea mays L.), (Blattduengung bei GemueseMais). Archives of Agronomy and Soil Science, 52 (4): 419-425.

Wang, Z.H. and Li S.X. (1996). Relationship between nitrate contents and water, total $\mathrm{N}$ as well as total $\mathrm{P}$ in different organs of vegetable plants. Plant Nutrition and Fertilizer Science, 2: 1444-1452.

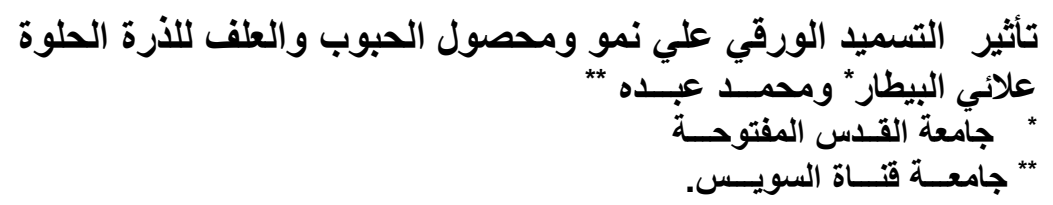

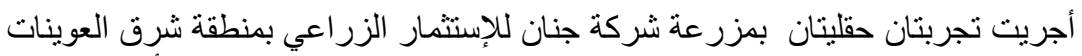

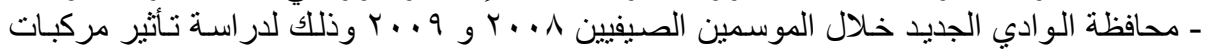

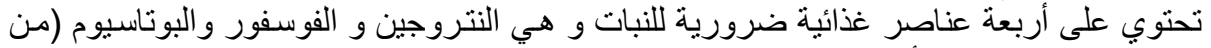

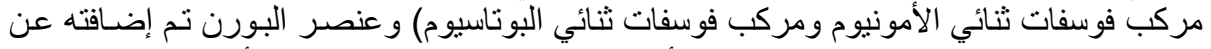

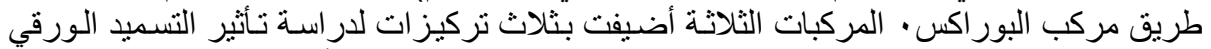

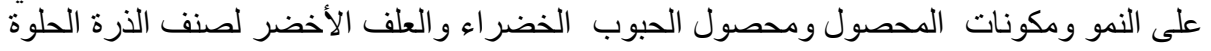

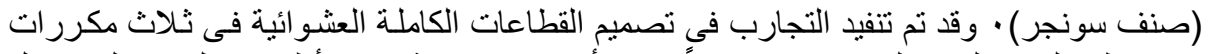

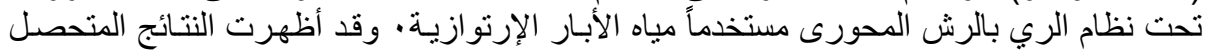

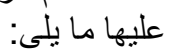

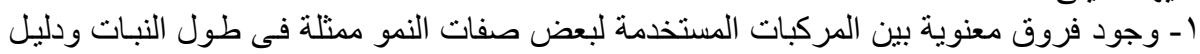

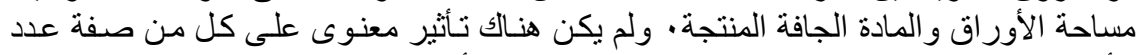

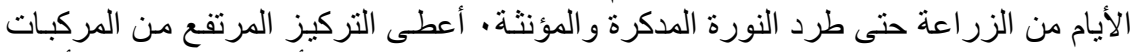

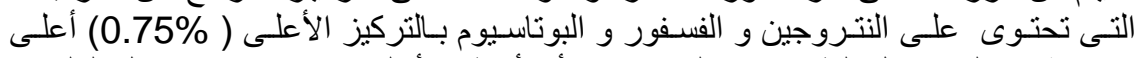

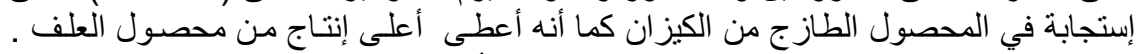

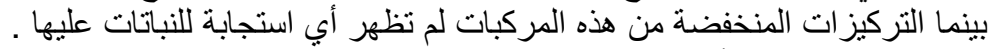

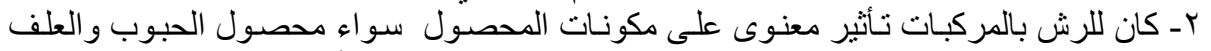

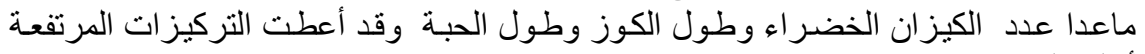

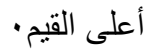

توصى الدر اسة للحصول على أعلى محصول من الكيزان و العلف الأخضر بالرش بالمو اد المختلفة بالتركيزات المرتفعة.

كلية الزراعة - جامعة المنصورة كلية الزراعة - جامعة الاسماعيليه
قام بتحكيم البحث

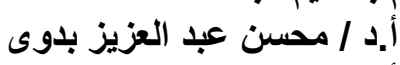

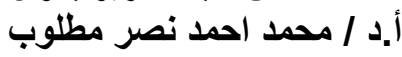

